Article

\title{
Strategies for Improving the E-Waste Management Supply Chain Sustainability in Indonesia (Jakarta)
}

\author{
Nurhadi Wibowo ${ }^{1,2}$, Jerry Kuswara Piton ${ }^{2}$, Rahmat Nurcahyo ${ }^{1, *(\mathbb{D}}$, Djoko Sihono Gabriel ${ }^{1}$, Farizal Farizal ${ }^{1}$ \\ and Alfian Ferdiansyah Madsuha ${ }^{3}$ (D)
}

1 Department of Industrial Engineering, Faculty of Engineering, Campus Baru UI, Universitas Indonesia, Depok 16424, Indonesia; nurh4diwibowo@gmail.com (N.W.); dsihono@gmail.com (D.S.G.); farizal@eng.ui.ac.id (F.F.)

2 National Research and Innovation Agency Republic of Indonesia (BRIN-RI), Jakarta 10340, Indonesia; jerrykuswara@gmail.com

3 Department of Metallurgical and Materials Engineering, Faculty of Engineering, Campus Baru UI, Universitas Indonesia, Depok 16424, Indonesia; alfian@eng.ui.ac.id

* Correspondence: rahmat@eng.ui.ac.id

Citation: Wibowo, N.; Piton, J.K.;

Nurcahyo, R.; Gabriel, D.S.; Farizal, F.; Madsuha, A.F. Strategies for Improving the E-Waste Management Supply Chain Sustainability in Indonesia (Jakarta). Sustainability 2021, 13, 13955. https://doi.org/ $10.3390 /$ su132413955

Academic Editor: Idiano D'Adamo

Received: 5 November 2021

Accepted: 13 December 2021

Published: 17 December 2021

Publisher's Note: MDPI stays neutral with regard to jurisdictional claims in published maps and institutional affiliations.

Copyright: (c) 2021 by the authors. Licensee MDPI, Basel, Switzerland. This article is an open access article distributed under the terms and conditions of the Creative Commons Attribution (CC BY) license (https:// creativecommons.org/licenses/by/ $4.0 /)$.

\begin{abstract}
Electronic waste (e-waste) has become one of the fastest-growing waste streams in the world. However, only $17.4 \%$ of it can be collected and recycled in 2019. This study aims to formulate strategies to improve the supply chain of e-waste management in Indonesia. Methods used to develop strategies in this study are the Decision-Making Trial and Evaluation Laboratory (DEMATEL), the Analytical Network Process (ANP), Strength-Weaknesses-Opportunities-Threats (SWOT), and the Quantitative Strategic Planning Matrix (QSPM). The results show that infrastructure criteria have the largest weight, that is 0.267 , followed by a social environment with 0.261 , regulation with 0.244 , stakeholder with 0.122 , and economy with 0.054 . The top priority of the selected strategies is to improve public education (ST1) and provide socialization of regulations and sanctions to the public (ST2).
\end{abstract}

Keywords: e-waste management; supply chain; strategy; environment; recycling; sustainability

\section{Introduction}

Electronic waste (e-waste) becomes one of the fastest-growing waste streams worldwide [1]. In 2019, a total of 53.6 million tons (Mt) of e-waste were produced across the world, which represents $21 \%$ in just 5 years. E-waste is divided into six main categories that are very suitable for the characteristics of their waste management. The categories are temperature changing equipment; panels and display screens; lights; large-size equipment; small-size equipment; small information technology; and telecommunication equipment; however, $17.4 \%$ of e-waste regenerated in 2019 can be recovered and recycled [2]. Indonesia leads with the highest Southeast Asian e-waste rate of 745 thousand tons/year, followed by Thailand with 418 thousand tons/year. Otherwise, Malaysia is next to Indonesia with 250 thousand tons/year and then Singapore with 109 thousand tons/year. However, Cambodia became the country with the lowest rate of e-waste in Southeast Asia, with 16 thousand tons/year. The high amount of e-waste in Indonesia needs to be balanced with an effective e-waste management infrastructure so that more opportunities for e-waste utilization in Indonesia may be pursued [3].

According to Santoso et al. [4], the average yearly growth rate of e-waste in Indonesia is $14.91 \%$. The overall amount of e-waste generated in Indonesia is expected to reach 49.6 million units (487 thousand tons) by 2028 [4]. In 2014, Indonesia contributed to 37\% of total e-waste; consequently, recycling facilities have to support the appropriate television recycling process [5]. However, because there are so few licensed recycling companies in Indonesia, most e-waste is dumped recklessly. The community disposes of e-waste 
mixed with household waste. Then, the informal sector sorts and processes it dangerously at the landfills, such as by open burning [6]. The television waste here is divided into Cathode-Ray Tube (CRT) and Flat-Panel Display (FPD), while the wastes it generates include plastic (43\%), iron (26\%), copper (16\%), aluminum $(13 \%)$, and glass (2\%), with only a small amount of gold and silver composition [6]. Given that plastic makes up the majority of waste composition (43\%), it has the potential to be recycled into a better result in terms of value added by the Material Value Conservation (MVC) method to reduce environmental problems [7].

Previous literature studies have identified three successful factors of e-waste management: regulation, stakeholders, and infrastructure [8]. Chen et al. [9] stated that the regulation of e-waste positively influences reducing the harmful risks from certain toxic substances. Lead $(\mathrm{Pb})$, beryllium $(\mathrm{Be})$, and mercury $(\mathrm{Hg})$ in e-waste can cause environmental harm and are toxic to humans if contaminated, which can cause damage to the brain's neurological system, disability, kidney damage, and other nasty things. It is estimated that $34 \%$ of the e-waste originating from several developed countries is sent to some developing countries, including illegal e-waste [10]. Countries with large industries such as China and India currently produce much e-waste coming from domestic sources and waste from outside, both legal and illegal. Meanwhile, developing countries such as Indonesia and Malaysia only regenerate e-waste in low amounts compared to developed countries with large industries. However, e-waste in developing countries is an economic opportunity for the second-hand market, as is the retrieval of valuable metals from e-waste [11]. Some developing countries in Southeast Asia, such as Indonesia, still import electronic goods to meet domestic needs. Indonesia is one of the developing countries which is a role player in the illegal traffic e-waste of the world. In 2005-2010, Indonesia's domestic authorities found illegal e-waste import cases, which eventually became a national issue. Indonesia is still using Indonesian Government Regulation No. 101 the Year 2014 on hazardous waste and e-waste [12]. Excellent and appropriate infrastructure can support e-waste management [13]; on the other hand, an inadequate infrastructure and facilities development and an insufficient budget can hamper e-waste management [14]. The government has a vital role in managing the supply chain of e-waste $[15,16]$. It also serves as a policyholder $[17,18]$ and can serve as a collection center for the e-waste supply chain management [19]. The collaboration of all partners, including political, consumer, industrial, and governmental desires, is necessary for integrated e-waste supply chain management [20].

Currently, the formal sector is having difficulty collecting the volume of e-waste that makes recycling economical. About $10 \%$ of e-waste can be absorbed; one of the reasons is that there are still few licensed recycling companies in Indonesia, thus resulting in the majority of scraps and residues from industry and businesses (including e-waste) being disposed of improperly [21]. In Indonesia, the special capital region of Jakarta's (Daerah khusus ibukota Jakarta or DKI Jakarta) provincial government has started to manage the e-waste supply chain in an integrated manner under the environment agency (Dinas lingkungan hidup or DLH) formally. Based on the study [21], the DKI Jakarta Province, with around 10 million people in 2014, can have 5 tons/year of e-waste from each population. That means that there is a potential for approximately 51 thousand tons of manageable e-waste. Based on data provided by the DLH [22], there were only 23 tons $(0.05 \%)$ that have been successfully managed through the DLH as the formal sector in 2020, and televisions occupied the top position with 12 tons.

The purpose of this study is to formulate a strategy of the formal sector, in this case, the DLH Jakarta, in managing the e-wastes of televisions and monitors as a supply of waste management industry in the DKI Jakarta. The formulation of strategies in the public sector is a valuable concept to design strategies in services to achieve government agencies' goals, expectations, and commitments. The preliminary stage of this study is to conduct a literature study to determine what factors can improve the e-waste management by the DLH Jakarta. In this study, there are three stages in formulating the strategies; the first stage is conducted using the Decision-Making Trial and Evaluation laboratory (DEMATEL) and 
Analytical Network Process (ANP) to obtain priorities of the criteria and sub-criteria in ewaste management. Both priorities obtained will be used to determine the strategies carried out at the next stage. The second stage will use the Matrix Internal Factor Evaluation (IFE) and External Factor Evaluation (EFE) to be further processed using the Matrix InternalExternal (IE) method. The Strength-Weaknesses-Opportunities-Threats (SWOT) method is a stage to obtain a viable alternative strategy by combining external and internal factors. The third stage is the decision stage, which is to obtain the weight of priorities of alternative strategies using the Quantitative Strategic Planning Matrix (QSPM) method.

\section{Literature Review}

\subsection{E-Waste Supply Chain Strategies}

Similar research regarding the supply chain of e-waste was carried out by Baidya et al. [19]. They identify the challenges and issues of the e-waste supply chain in India using the analytical hierarchy process (AHP) and quality function deployment (QFD). Anityasari et al. [8] analyze factors that can improve e-waste collection by the informal sector using AHP in Indonesia. Furthermore, Ghalehkhondabi and Ardjmand [23] used game theory to state that recycling centers must integrate with the e-waste supply chain process to profit in Brazil. This research integrated the Decision-Making Trial and Evaluation laboratory (DEMATEL), the Analytical Network Process (ANP), Strength-Weaknesses-OpportunitiesThreats (SWOT) and the Quantitative Strategic Planning Matrix (QSPM). The DEMATEL approach can solve complex problems and find solutions. This principle helps to show the links between variables and items by confirming them. DEMATEL data can be utilized in ANP to assess the interdependence of several variables [24]. SWOT and QSPM analyses can be used to determine if a firm is in a highly competitive environment and what actions need to be taken for future strategic planning. It can assist decision makers in developing a company's future roadmap [25].

\subsection{Communities Behavioral Intention}

The behavioral intention of the community to take part in recycling electronic waste is one of the essential elements in planning electronic waste management [26]. The success of electronic waste management is very dependent on the involvement of communities to recycle. Knowing public perceptions of recycling e-waste is crucial to formulate the right policy to deal with electronic waste problems [26]. Some previous studies regarding the attitudes and behavior of the community to recycle. Nduneseokwu et al. [27] found that attitudes, subjective norms, and environmental knowledge influenced community participation in gathering e-waste for recycling. Xu et al. [28] reported that demographic factors such as age, income, and educational level influence a community's desire to recycle. Dwivedy and Mittal [29] stated that the ease of place and habit affected a community to recycle.

\subsection{Reverse Logistics Barrier}

Reverse Logistics (RL) is one of the critical parts of implementing e-waste management [30]. They analyzed the barrier that affected the stakeholder in implementing RL, where infrastructure became a factor of internal and legislative barriers to the most critical external barrier. Research on the review and interests for the future of e-waste Reverse Logistics was conducted by Doan et al. [20]. There are four main groups: implementation factors, performance evaluation and decision making, product returns, and network design. Ghalehkhondabi and Ardjmand [23] carry out sustainable e-waste supply chain management and its relation to prices and government intervention. Research on reverse logistics and closed-loop supply chain and literature review by Islam and Huda [16] obtained four types of research: reverse distribution design and planning, decision making and performance evaluation, conceptual framework, and the identification of qualitative study. 


\subsection{Waste Printed Circuit Boards}

Printed circuit boards (PCB) are the most valuable element in electronic waste [31]. D'Adamo et al. [32] stated that PCB processing can be performed sustainably based on the results of the profitability analysis that has been carried out in their study. Ghodrat et al. [33] showed that sales revenue was the most sensitive factor in the recycling process. Xue et al. [34] stated that the payback period in the recycling process was relatively short of 2.5 years. Zeng found that profits in carrying out a recycling process reached $83 \mathrm{USD} /$ ton if the operation was carried out in developing countries. However, based on profit, gold plays a role, followed by palladium and copper, which does not require a high cost in the process [32].

\section{Materials and Methods}

\subsection{Determination of Criteria and Sub-Criteria}

In determining a goal, criteria must be determined first so that success can be seen in the evaluation. The main objective at this stage is to obtain priority strategies based on criteria to increase collection of television e-waste. The criteria and sub-criteria were obtained from various literature, yielding 5 criteria and 18 sub-criteria. Table 1 shows regulatory criteria with sub-criteria: Waste management regulation in the household sector affects the handling of e-waste of televisions and monitor devices generated by household consumers (RE1) [35]; regulation and sanctions affect minimizing the e-waste management in the informal sector (RE2) [2]; regulation of e-waste management in the DLH Jakarta Provincial Government affects the handling of e-waste (RE3) [16]; regulation on the role of influential producers in the e-waste management of televisions and monitor devices (RE4) [5]; regulation and ease of permits to the formal industry of e-waste recycling televisions and monitor devices are influential in the e-waste management (RE5) [16].

Table 1. Regulation criteria and sub-criteria.

\begin{tabular}{clcc}
\hline Criteria & \multicolumn{1}{c}{ Sub-Criteria } & Code & Ref. \\
\hline & $\begin{array}{l}\text { Waste management regulation in the household sector affects } \\
\text { the handling of e-waste of televisions and monitor devices } \\
\text { generated by household consumers }\end{array}$ & RE1 & [35] \\
\cline { 2 - 4 } Regulation & $\begin{array}{l}\text { Regulation and sanctions affect minimizing the e-waste } \\
\text { management in the informal sector }\end{array}$ & RE2 & [2] \\
\cline { 2 - 4 } & $\begin{array}{l}\text { Regulation of e-waste management in the DLH Jakarta } \\
\text { Provincial Government affects the handling of e-waste. }\end{array}$ & RE3 & [16] \\
\cline { 2 - 4 } & $\begin{array}{l}\text { Regulation on the role of influential producers in the e-waste } \\
\text { management of televisions and monitor devices }\end{array}$ & RE4 & [5] \\
\cline { 2 - 4 } & $\begin{array}{l}\text { Regulation and ease of permits to the formal industry of e-waste } \\
\text { recycling televisions and monitor devices are influential in the } \\
\text { e-waste management }\end{array}$ & RE5 & [16] \\
\hline
\end{tabular}

Table 2 shows infrastructure criteria with sub-criteria: Adequate shelters play a role in the e-waste recycling of televisions and monitor devices (IN1) [35]; easy access to e-waste collection plays a role in the e-waste recycling of televisions and monitor devices (IN2) [2]; pick-up facilities for e-waste of televisions and monitor devices affect e-waste management (IN3) [22]; social media is influential in the e-waste of television electronics and monitor devices (IN4) [2]. 
Table 2. Infrastructure criteria and sub-criteria.

\begin{tabular}{clcc}
\hline \multicolumn{1}{c}{ Criteria } & \multicolumn{1}{c}{ Sub-Criteria } & Code & Ref. \\
\hline & $\begin{array}{l}\text { Adequate shelters play a role in the e-waste recycling of } \\
\text { televisions and monitor devices }\end{array}$ & IN1 & [35] \\
\cline { 2 - 4 } Infrastructure & $\begin{array}{l}\text { Easy access to e-waste collection plays a role in the e-waste } \\
\text { recycling of televisions and monitor devices }\end{array}$ & IN2 & [2] \\
\cline { 2 - 4 } & $\begin{array}{l}\text { Pick-up facilities for e-waste of televisions and monitor devices } \\
\text { affects e-waste management }\end{array}$ & IN3 & [22] \\
\cline { 2 - 4 } & $\begin{array}{l}\text { Social media is influential in the e-waste television electronics } \\
\text { and monitor devices }\end{array}$ & IN4 & [2] \\
\hline
\end{tabular}

Table 3 shows stakeholder criteria with sub-criteria: knowledge of influential people on proper e-waste management (SH1) [35]; extended producer responsibility (EPR) affects the e-waste management of television electronics and monitor devices (SH2) [36]; the device of DLH from the sub-district to the province affects the e-waste management of television electronics and monitor devices (SH3) [22]; formal processing companies that have permits to influence the e-waste management of electronics and monitor devices (SH4) [6].

Table 3. Stakeholder criteria and sub-criteria.

\begin{tabular}{|c|c|c|c|}
\hline Criteria & Sub-Criteria & Code & Ref. \\
\hline \multirow{4}{*}{ Stakeholder } & Knowledge of influential people on proper e-waste management & SH1 & [35] \\
\hline & $\begin{array}{l}\text { Extended producer responsibility (EPR) affects the e-waste } \\
\text { management of television electronics and monitor devices }\end{array}$ & $\mathrm{SH} 2$ & [36] \\
\hline & $\begin{array}{l}\text { The device of DLH from the sub-district to the province affects } \\
\text { the e-waste management of television electronics and monitor } \\
\text { devices. }\end{array}$ & $\mathrm{SH} 3$ & [22] \\
\hline & $\begin{array}{l}\text { Formal processing companies that have permits to influence the } \\
\text { e-waste management of electronics and monitor devices }\end{array}$ & $\mathrm{SH} 4$ & [6] \\
\hline
\end{tabular}

Table 4 shows economic criteria with sub-criteria: exchange rate of e-waste for consumers with a specific economic value in the formal sector affects the e-waste management of television electronics and monitor devices (FI1) [18]; tax incentives (subsidies) for ewaste management in the formal sector affect the e-waste of management and monitor devices (FI2) [35].

Table 4. Economics criteria and sub-criteria.

\begin{tabular}{clcc}
\hline Criteria & \multicolumn{1}{c}{ Sub-Criteria } & Code & Ref. \\
\hline \multirow{3}{*}{ Economics } & $\begin{array}{l}\text { Exchange rate of e-waste for consumers with a specific economic } \\
\text { value in the formal sector effect the e-waste management } \\
\text { television electronics and monitor devices }\end{array}$ & FI1 & [18] \\
\cline { 2 - 4 } & $\begin{array}{l}\text { Tax incentives (subsidies) for e-waste management in the formal } \\
\text { sector affect the e-waste of management and monitor devices }\end{array}$ & FI2 & [35] \\
\hline
\end{tabular}

Table 5 shows environmental social criteria with sub-criteria: public awareness of the dangers of e-waste affects the e-waste management televisions and monitor devices (SL1) [35]; awareness of the dangers of e-waste in the educational environment affects the e-waste management of televisions and monitor devices (SL2) [35]; socialization and education affect the e-waste management of televisions and monitor devices (SL3) [8]. 
Table 5. Environmental social criteria and sub-criteria.

\begin{tabular}{|c|c|c|c|}
\hline Criteria & Sub-Criteria & Code & Ref. \\
\hline \multirow{3}{*}{ Environmental } & $\begin{array}{l}\text { Public awareness of the dangers of e-waste affects the e-waste } \\
\text { management of televisions and monitor devices }\end{array}$ & SL1 & [35] \\
\hline & $\begin{array}{l}\text { Awareness of the e-waste dangers in the educational } \\
\text { environment affects the e-waste management of televisions and } \\
\text { monitor devices }\end{array}$ & SL2 & [35] \\
\hline & $\begin{array}{l}\text { Socialization and education affect the e-waste management } \\
\text { televisions and monitor devices }\end{array}$ & SL3 & [8] \\
\hline
\end{tabular}

The determination of criteria and sub-criteria needs to be tested using questionnaires given to experts using a Likert scale from 1 to 5 to measure the importance of each criterion and sub-criterion. The results are then weighted and measured using geometric averages. As many as six respondents were selected for the questionnaire, of whom two are experts from the DLH Jakarta with experience of 15-20 years, one expert with research experience $>20$ years, two experts from academics with experience $>20$ years, and parties who understand e-waste recycling with experience 10 years. The geomean result with a mean value of less than 3.5 will be eliminated and considered to have no significant effect.

\subsection{Integration of DEMATEL-ANP}

After obtaining the results of the geomean calculation, the second stage questionnaire was conducted by analyzing the experts' opinions on influence factors incorporated into the matrix answer sheet and analyzed using the DEMATEL method to obtain the influence matrix or direct relationships between criteria from one to another. In this stage, the data collection process was conducted using closed-ended questionnaires. The questionnaires aim to find the inner dependence or outer dependence between criteria and sub-criteria. They were shared directly with each respondent via email and WhatsApp. Each of them consists of an introduction explaining that this is for academic research purposes so that it is expected to be answered in accordance with the actual conditions. It also explained how to fill out the questionnaires in determining the interdependent relationships between criteria in one group (inner dependence) or between groups (outer dependence) with 5 criteria and 18 sub-criteria. Each respondent was asked to fill in the cell that connects the two criteria and the sub-criteria whether there is a criterion or sub-criterion that affects the other criteria or sub-criteria. The scales used were from 0 to 4 , namely, 0 (no influence), 1 (low influence), 2 (moderate influence), 3 (high influence), and 4 (very high influence). The average value of respondents was used for the calculation of the DEMATEL method. After obtaining the influence relationship between sub-criteria, a model was then made using Super Decision Software Windows Version 2.10.

The ANP model between criteria and sub-criteria employed in the study using a second-stage questionnaire is depicted in Figure 1 above. The existence of a line connecting two sub-criteria implies that they are related. Loops contained in each sub-criteria in a criterion describe the relationship between sub-criteria that is within the criteria (inner dependence), while the line connecting between sub-criteria shows the relationship between sub-criteria under different criteria (outer dependence). At this stage, the collection data process using the third stage questionnaire was performed. The questionnaire aims to find out the comparison of pairs between criteria and sub-criteria by experts in the calculations of weighted in ANP based on the results of the second stage questionnaire. After obtaining the priority of sub-criteria in the e-waste management supply chain, selecting sub-criteria was carried out in the next stage, namely, the establishment of priority factors for the e-waste management supply chain from the ANP results. The selection of factors was based on sub-criteria using a Pareto diagram [37], where $20 \%$ gives $80 \%$ effect for the overall e-waste supply chain management activities in DLH Jakarta. The selection with 
Pareto aims to see a significant risk effect to provide an effect of $80 \%$ for e-waste supply chain management activities.

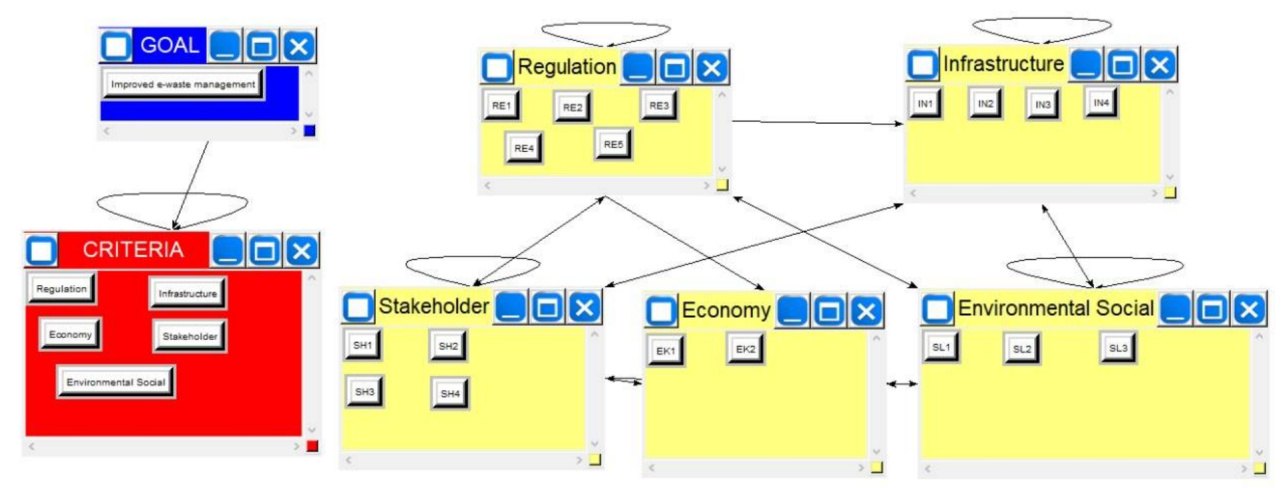

Figure 1. The ANP Model with Super Decision Software.

\subsection{Strategies Formulation to Improve E-waste Management}

The determination of criteria and sub-criteria priorities was used as the basis for determining internal and external factors of DLH Jakarta in the formulation phase of the strategy of improving e-waste management. The internal and external factors of DLH were obtained based on the results of the survey of factors that affect e-waste management and by conducting a library study of related documents.

In the fourth stage questionnaire, six strengths and four weaknesses were found to be in internal factors. While on external factors, seven opportunities and four threats were obtained (Table 6). Furthermore, the fifth stage questionnaire was performed to obtain the IFE and EFE matrices, and a matching method was performed through SWOT matrix analysis. Through that, eight alternative strategies were obtained, based on matching with strength, weakness, opportunity, threat, and IE matrix factors. The final stage of this study was to calculate the alternative QSPM rating through the sixth stage questionnaire so that the ranking of strategies in the e-waste management of televisions and monitor screens in DLH-DKI Jakarta was obtained.

Table 6. SWOT List.

\begin{tabular}{l} 
Strengths \\
\hline $\begin{array}{l}\text { Organization of DLH Jakarta. In accordance with the } \\
\text { Regulation of the Governor of the special Capital Region of }\end{array}$ \\
1. Jakarta Province Number 284 of 2016 regarding the \\
$\begin{array}{l}\text { Organization and Work Procedure of DLH in carrying out } \\
\text { environmental protection and management and } \\
\text { hygiene management. }\end{array}$
\end{tabular}

2. E-waste pick-up service for any e-waste weighing over $5 \mathrm{~kg}$.

3raining, workshops, and seminars on e-waste management to stakeholders in DLH-DKI Jakarta.
1. Quality of human resources in the e-waste management in the provincial environment agency to the sub-agency.

Adequate supporting infrastructure facilities such as drop

2. boxes, landfills (TPS), storage warehouses, and transport vehicles scattered in the administrative municipal sub-agency of the special capital region of Jakarta.

3. Budget for the implementation of e-waste management in planning to the implementation in DKI Jakarta.

The existence of regulation of e-waste management along

4. with its implementation and the stages of its procedures (SOP).

Access to information, services, and ease of service access

5. through the DLH web, including socialization and education on the dangers of e-waste.
4. Quantity of human resources in the e-waste management in the provincial DLH to the sub-agency.

6. Enforcement of environmental law sanctions. 
Table 6. Cont.

\section{Opportunities}

\section{Threats}

The existence of government agencies, law enforcement

1. agencies, and NGOs that pay attention to the environmental pollution.

1. The economic benefits obtained from the e-waste collection for the community.

Educational institutions in DKI Jakarta located in DKI

2. Jakarta more than 5000 make an opportunity to carry out education and socialization early in the educational environment.

The availability of formal and licensed e-waste management

3. companies and can accept various types of existing e-waste conditions.
2. The community's desire to collect e-waste.

Demographic conditions of the DKI Jakarta population.

3. Spread with various conditions and locations, and various

conditions of society from the educational, social, economic side.

E-waste management in the informal sector, in the form of

4. collecting, dismantling, and burning e-waste that adversely affects the environment.

5. processing company that will provide economic value to the

community that will collect e-waste but with the physical condition of certain e-waste.

6. Public awareness and knowledge of the dangers of e-waste.

The existence of waste-producing companies and other

7. companies in DKI Jakarta that pay attention to environmental pollution.

\section{Results}

In determining the criteria and sub-criteria determined using the first stage questionnaire, all sub-criteria have a geomean value of $>3.5$. The results indicate that all criteria and sub-criteria can be used and have an influence on improving the e-waste management of televisions and monitor screens in DKI Jakarta, represented in Table 7. The result then became a reference to carry out the second stage questionnaire with the DEMATEL method to obtain the interrelationships between criteria and sub-criteria where there are 5 criteria and 18 sub-criteria, each of which is looking for a relationship, where the Total-Relation Matrix table with an obtained Threshold (alpha) value of 0.7128 , which can be used as a reference value of inter-criteria. Once the relationship between the criteria and sub-criteria is obtained, the next step can compare pairs using the ANP method. Based on the results of the third stage questionnaire regarding the ranking of the criteria of processing results with super decision software, it is known that the infrastructure criteria have the largest weight, that is, 0.26762 , followed by a social environment with 0.26162 , regulation with 0.24418 , stakeholders with 0.12227 , and economy with 0.05430 . The highest sub-criteria, in order, are SL1, IN2, SL3, SL2, IN3, RE1, SH1, RE4, IN1, RE3, SH2, IN4, RE2, SH3, EK2, SH4, RE5, and EK1, which is represented in Table 8. This shows the importance of public awareness of the dangers of e-waste to the environment and humans. Increased public awareness can also be supported by easy access to e-waste collection in strategic places and easy public access supported by socialization and education. To obtain effective results, it is also necessary to increase the sub-criteria that has the greatest weight, regardless of the same criteria. The sub-criteria needed to be considered for the improvement of the e-waste management of televisions and monitor screens in DKI Jakarta using Pareto were in the sub-criteria of EK2, IN1, IN3, IN1, RE1, RE4, RE3, SL1, SL3, SL2, SH1, SH2, and SH3. After gaining a large impact sub-criteria weight using Pareto, the next step was to identify the internal and external factors to obtain the strengths, weaknesses, opportunities, and threats. From the fourth stage questionnaire results, six strengths and four weaknesses were found in the internal factors. While in the external factors, seven opportunities and four threats were obtained, as shown in Table 9. Then, a fifth stage questionnaire was performed to 
obtain the IFE and EFE matrices. The calculation of both matrices successfully obtained the IFE matrix value of 2.70 and the EFE matrix value of 3.45 .

Table 7. The results of processing criteria and sub-criteria data.

\begin{tabular}{|c|c|c|c|c|}
\hline Criteria & Sub-Criteria & Code & Geomean & Results \\
\hline \multirow{5}{*}{ Regulation } & Waste management regulation in the household sector & RE1 & 4.54 & Accepted \\
\hline & $\begin{array}{l}\text { Regulation and sanctions affect minimizing the e-waste management } \\
\text { in the informal sector }\end{array}$ & RE2 & 4.09 & Accepted \\
\hline & $\begin{array}{l}\text { Regulation of e-waste management in the environment agency of } \\
\text { Jakarta Provincial Government }\end{array}$ & RE3 & 4.09 & Accepted \\
\hline & $\begin{array}{l}\text { Regulation on the role of influential producers in the e-waste } \\
\text { management of televisions and monitor devices }\end{array}$ & RE4 & 4.40 & Accepted \\
\hline & $\begin{array}{l}\text { Regulation and ease of permits to the formal industry of e-waste } \\
\text { recycling of televisions and monitor devices are influential in the } \\
\text { e-waste management }\end{array}$ & RE5 & 4.54 & Accepted \\
\hline \multirow{4}{*}{ Infrastructure } & $\begin{array}{l}\text { Adequate shelters play a role in the e-waste recycling of televisions } \\
\text { and monitor devices }\end{array}$ & IN1 & 5.00 & Accepted \\
\hline & $\begin{array}{l}\text { Easy access to e-waste collection plays a role in the e-waste recycling } \\
\text { of televisions and monitor devices }\end{array}$ & IN2 & 4.54 & Accepted \\
\hline & $\begin{array}{l}\text { E-waste of televisions and monitor devices pick-up facilities and affect } \\
\text { the e-waste management }\end{array}$ & IN3 & 4.84 & Accepted \\
\hline & $\begin{array}{l}\text { Social media is influential in the e-waste television electronics and } \\
\text { monitor devices }\end{array}$ & IN4 & 4.40 & Accepted \\
\hline \multirow{4}{*}{ Stakeholder } & Knowledge of influential people on proper e-waste management & SH1 & 4.54 & Accepted \\
\hline & $\begin{array}{l}\text { Extended producer responsibility (EPR) affects the e-waste } \\
\text { management of television electronics and monitor devices }\end{array}$ & $\mathrm{SH} 2$ & 4.54 & Accepted \\
\hline & $\begin{array}{l}\text { The device of DLH Jakarta from the sub-district to the province affects } \\
\text { the e-waste management of television electronics and monitor devices }\end{array}$ & SH3 & 3.96 & Accepted \\
\hline & $\begin{array}{l}\text { Formal processing companies that have permits to influence the } \\
\text { e-waste management of electronics and monitor devices }\end{array}$ & SH4 & 4.26 & Accepted \\
\hline \multirow[t]{2}{*}{ Economy } & $\begin{array}{l}\text { Exchange rate of e-waste for consumers with a specific economic } \\
\text { value in the formal sector effect the e-waste management television } \\
\text { electronics and monitor devices }\end{array}$ & EK1 & 4.26 & Accepted \\
\hline & $\begin{array}{l}\text { Tax incentives (subsidies) to the e-waste management formal sector } \\
\text { affect the e-waste of management and monitor devices }\end{array}$ & EK2 & 4.13 & Accepted \\
\hline \multirow{3}{*}{ Social-Environment } & $\begin{array}{l}\text { Environmental social criteria with sub-criteria: Public awareness of } \\
\text { the dangers of e-waste, affect the e-waste management televisions and } \\
\text { monitor devices }\end{array}$ & SL1 & 4.84 & Accepted \\
\hline & $\begin{array}{l}\text { Awareness of the e-waste dangers in the educational environment } \\
\text { affects the e-waste management of televisions and monitor devices }\end{array}$ & SL2 & 4.26 & Accepted \\
\hline & $\begin{array}{l}\text { Socialization and education affect the e-waste management } \\
\text { televisions and monitor devices }\end{array}$ & SL3 & 4.69 & Accepted \\
\hline
\end{tabular}


Table 8. Criteria and sub-criteria priority results.

\begin{tabular}{|c|c|c|c|c|}
\hline & Name & Normalized by Cluster & Limiting & Rank \\
\hline \multirow{2}{*}{$\begin{array}{l}\text { Economy } \\
(0.05430)\end{array}$} & EK1 & 0.06162 & 0.00095 & 18 \\
\hline & EK2 & 0.93838 & 0.01445 & 15 \\
\hline \multirow{4}{*}{$\begin{array}{l}\text { Infrastructure } \\
\quad(0.26762)\end{array}$} & IN1 & 0.17380 & 0.04868 & 9 \\
\hline & IN2 & 0.38991 & 0.10920 & 2 \\
\hline & IN3 & 0.34082 & 0.09545 & 5 \\
\hline & IN4 & 0.09547 & 0.02674 & 12 \\
\hline \multirow{5}{*}{$\begin{array}{l}\text { Regulation } \\
(0.24418)\end{array}$} & RE1 & 0.37453 & 0.07810 & 6 \\
\hline & RE2 & 0.12202 & 0.02545 & 13 \\
\hline & RE3 & 0.23095 & 0.04816 & 10 \\
\hline & RE4 & 0.25122 & 0.05239 & 8 \\
\hline & RE5 & 0.02128 & 0.00444 & 17 \\
\hline \multirow{3}{*}{$\begin{array}{l}\text { Social-Environment } \\
\qquad(0.26162)\end{array}$} & SL1 & 0.43745 & 0.16373 & 1 \\
\hline & SL2 & 0.27551 & 0.10312 & 4 \\
\hline & SL3 & 0.28704 & 0.10743 & 3 \\
\hline \multirow{4}{*}{$\begin{array}{c}\text { Stakeholder } \\
(0.17227)\end{array}$} & SH1 & 0.46796 & 0.05696 & 7 \\
\hline & $\mathrm{SH} 2$ & 0.24779 & 0.03016 & 11 \\
\hline & $\mathrm{SH} 3$ & 0.17466 & 0.02126 & 14 \\
\hline & $\mathrm{SH} 4$ & 0.10959 & 0.01334 & 16 \\
\hline
\end{tabular}

Table 9. SWOT Matrix

\begin{tabular}{|c|c|c|c|}
\hline & & S1-S6 & W1-W4 \\
\hline & & S-O Strategy & W-O Strategy \\
\hline \multirow{4}{*}{ O1-O7 } & 1. & $\begin{array}{l}\text { Developing cooperation with all stakeholders in } \\
\text { e-waste management, including educational } \\
\text { institutions in the DKI Jakarta environment, } \\
\text { government and non-government institutions, as } \\
\text { well as e-waste processing companies that can } \\
\text { provide economic value under certain conditions } \\
\text { and companies that receive e-waste with various } \\
\text { existing physical conditions (S1, S3, O1, O2, O3, } \\
\text { O5, O7) }\end{array}$ & $\begin{array}{l}\text { Improving the quality and quantity of human } \\
\text { resources of DLH Jakarta from the provincial level } \\
\text { to the sub-agency and establishing cooperation } \\
\text { with government and non-government institutions, } \\
\text { including educational institutions for education } \\
\text { and socialization of e-waste management (W1, W4, } \\
\text { O1, O2) }\end{array}$ \\
\hline & 2. & $\begin{array}{l}\text { Improving access to information and ease of } \\
\text { access to management services including e-waste } \\
\text { pick-up through various access methods in order } \\
\text { to increase knowledge and public awareness (S2, } \\
\text { S5, O6) }\end{array}$ & $\begin{array}{l}\text { Improving facilities, infrastructure, and budget } \\
\text { optimization through EPR and increasing } \\
\text { cooperation with e-waste processing companies } \\
\text { that can provide economic value under certain } \\
\text { conditions and companies that that accept the } \\
\text { existing physical conditions (W2, W3, O3, O5, O7) }\end{array}$ \\
\hline & 3. & $\begin{array}{l}\text { Implementing e-waste management regulations } \\
\text { from the central government and make SOP and } \\
\text { environmental law enforcement }(\mathrm{S} 4, \mathrm{~S} 6, \mathrm{O} 4)\end{array}$ & - \\
\hline & & S-T Strategy & W-T Strategy \\
\hline \multirow{2}{*}{$\mathrm{T} 1-\mathrm{T} 4$} & 1. & $\begin{array}{l}\text { Improving education, socialization, and } \\
\text { information services to increase public's desire } \\
\text { across various demographic conditions through } \\
\text { various media access (S2, S3, S5, T1, T2, T3) }\end{array}$ & $\begin{array}{l}\text { Optimization of budgets to improve waste } \\
\text { collection facilities in various public locations to } \\
\text { increase public's desire to collect e-waste under } \\
\text { diverse demographic conditions (W2, W3, T2, T3) }\end{array}$ \\
\hline & 2. & $\begin{array}{l}\text { Providing socialization and education on the } \\
\text { application of regulations and sanctions to } \\
\text { informal sector e-waste managers who conduct } \\
\text { demolition and burning of e-waste that adversely } \\
\text { affects the environment (S3, S4, S6, T4) }\end{array}$ & - \\
\hline
\end{tabular}


Furthermore, a matching method was performed through a SWOT matrix analysis. Through that, eight alternative strategies were obtained based on matching with strength, weakness, opportunity, threat, and IE matrix factors. The final stage of this study was to calculate the alternative QSPM rating through the sixth stage questionnaire so that the ranking of strategies in the e-waste management of televisions and monitor screens in DLH Jakarta was obtained.

Strategies obtained based on the highest to lowest Total Attractiveness Scores (TAS) in order were the strategy providing socialization and education on the application of regulations and sanctions to informal sector e-waste managers who conduct demolition and burning of e-waste that adversely affects the environment (ST2); improving education, socialization, and information services to increase the public's desire across various demographic conditions through various media (ST1); developing cooperation with all stakeholders in e-waste management, including educational institutions in the DKI Jakarta environment, government and non-government institutions, as well as e-waste processing companies that can provide economic value under certain conditions and companies that receive e-waste with various existing physical conditions (SO1); improving facilities, infrastructure, and budget optimization through EPR and increasing cooperation with e-waste processing companies that can provide economic value under certain conditions and companies that accept the existing physical conditions (WO2); optimization of budgets to improve waste collection facilities in various public locations to increase the public's desire to collect e-waste under diverse demographic conditions (WT1); improving the quality and quantity of the human resources of DLH Jakarta from the provincial level to the sub-agency level and establishing cooperation with government and non-government institutions, including educational institutions for the education and socialization about e-waste management (WO1); improving access to information and ease of access to management services including e-waste pick-up through various access methods in order to increase knowledge and public awareness (SO2); and the lowest score was implementing e-waste management regulations from the central government, making standard operating procedures (SOP) and environmental law enforcement (SO3).

\section{Discussion}

The Strengths-Weaknesses-Opportunities-Threats (SWOT) Matrix is an important matching tool that helps managers develop four types of strategies: the SO Strategy (Strengths-Opportunities), the WO Strategy (Weaknesses-Opportunities), the ST Strategy (Strengths-Threats), and the WT Strategy (Weaknesses-Threats). Matching key external and internal factors are the most challenging part of developing a SWOT Matrix and requires good judgment [30]. The SO strategy uses the company's internal power to take advantage of existing external opportunities. The WO strategy aims to correct the internal weaknesses by leveraging external opportunities. Sometimes, there are major external opportunities, but the company has internal weaknesses that prevent it from taking advantage of those opportunities. The ST strategy uses the company's strengths to avoid or reduce the impact of external threats, and the WT strategy is a defensive tactic directed to reduce the internal weaknesses and avoid external threats. In this study, the calculation of IFE and EFE matrices obtained the IFE matrix value of 2.70 and the EFE matrix value of 3.45. Both numbers were used as the coordinates of the $x$ - and $y$-axes, so that both matrix values are in cell II, which can be seen in Figure 2; this can be described as a growing and developing organization. Intensive (market penetration, market development, and product development) or integrative (backward integration, forward integration, and horizontal integration) strategies can be the most appropriate for this division. Another important thing is to study the community's behavior in recycling electronic waste [26]. The success of electronic waste management depends on communities' involvement in recycling [26]. According to Vieira et al. [30], knowing the barrier faced in reverse logistics is another essential thing so that electronic waste management can run well. D'adamo et al. [32] 
stated that PCB is currently one of the most valuable electronic waste to realize sustainable electronic waste management.

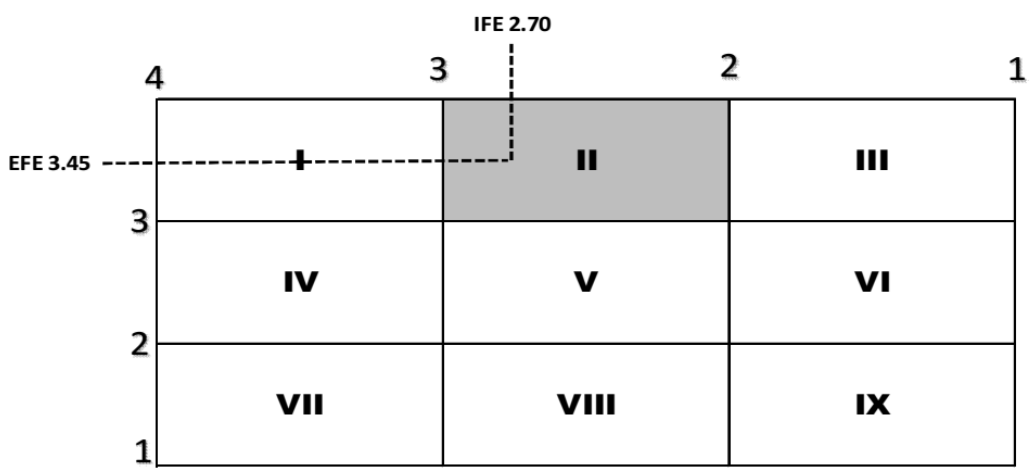

Figure 2. Quadrant of the IE Matrix.

In this study, the QSPM method was used to rank priority strategies in order to determine the relative attractiveness of viable alternative actions [38]. QSPM is a method that allows strategists to objectively evaluate alternative strategies based on previously identified external and internal critical success factors. The QSPM, similar to other strategy formulation analysis tools, demands good intuitive assessment. This matching tool generally produces similar viable alternatives. However, not every strategy suggested by the matching technique should be evaluated in QSPM. The QSPM matrices are created based on the internal and external factors in the EFE, IFE, and SWOT matrices.

The QSPM technique is intended to determine relative attractiveness and evaluate alternative strategy choices that can be made objectively based on internal and external factors identified by experts in previous EFE and IFE matrices. It is the final stage matrix in the strategy formulation analytical framework [38]. The obtained strategy and Total Attractiveness Scores (TAS) can be seen in Table 10. The priority strategy showed by the highest TAS value.

Table 10. QSPM Priority Strategy.

\begin{tabular}{cc}
\hline Strategy & TAS Value \\
\hline (ST2) & 5.92 \\
$(\mathrm{ST} 1)$ & 5.91 \\
$(\mathrm{SO} 1)$ & 5.82 \\
$(\mathrm{WO} 2)$ & 5.73 \\
$(\mathrm{WT} 1)$ & 5.70 \\
$(\mathrm{WO} 1)$ & 5.57 \\
$(\mathrm{SO} 2)$ & 5.55 \\
$(\mathrm{SO} 3)$ & 5.40 \\
\hline
\end{tabular}

\section{Conclusions}

The amount of e-waste has increased significantly in developing countries such as Indonesia due to the amount of illegally imported waste and a lack of regulations that can support the management of electronic waste properly. Improving the performance of the supply chain collection of electronic waste is focused on a proper strategy to make it happen, especially in the formal sector. This study provides input on the right strategy in improving the supply chain of e-waste management. Strategies obtained from the highest to lowest TAS values in order, namely: providing socialization and education on the application of regulations and sanctions to informal sector e-waste managers who conduct demolition and burning of e-waste that adversely affects the environment (ST2); improving education, socialization, and information services to increase the public's desire across various demographic conditions through various media accesses (ST1); developing 
cooperation with all stakeholders in the e-waste management, including educational institutions in the DKI Jakarta environment, government and non-government institutions, as well as e-waste processing companies that can provide economic value under certain conditions and companies that receive e-waste with various existing physical conditions (SO1); improving facilities, infrastructure, and budget optimization through EPR and increasing cooperation with e-waste processing companies that can provide economic value under certain conditions and companies that accept the existing physical conditions (WO2); optimization of budgets to improve waste collection facilities in various public locations to increase the public's desire to collect e-waste under diverse demographic conditions (WT1); improving the quality and quantity of the human resources of DLH Jakarta from the provincial level to the sub-agency level and establishing cooperation with government and non-government institutions, including educational institutions for the education and socialization of e-waste management (WO1); improving access to information and ease of access to management services including e-waste pick-up through various access methods in order to increase knowledge and public awareness (SO2); and with the lowest TAS value is implementing e-waste management regulations from the central government and making SOP and environmental law enforcement (SO3).

The stages given in this study can assist in identifying, evaluating, and choosing the right strategies. Formal-sector actors in the collection of e-waste, one of which is DLH Jakarta, can use this study to reformulate the vision and mission, identify opportunities and threats external to the organization, discover internal strengths and weaknesses, set long-term goals, and generate alternative strategies as well, so as to prepare support for strategies such as creating an effective organizational structure, directing marketing efforts, preparing budgets, and developing and utilizing information systems. In the future, formal sector actors in e-waste management should always be able to make modifications to the strategy by evaluating the fundamental strategy, namely, reviewing external and internal factors which are the basis of the current strategy; measuring performance and taking corrective action due to constant changes in external and internal factors.

Author Contributions: Conceptualization, N.W. and J.K.P.; data curation, N.W.; formal analysis, N.W.; funding acquisition, R.N.; investigation, N.W. and J.K.P.; methodology, N.W.; project administration, N.W.; resources, N.W. and J.K.P.; software, N.W. and J.K.P.; supervision, R.N., D.S.G., F.F., and A.F.M.; validation, N.W. and J.K.P.; visualization, N.W.; writing-original draft, N.W.; writing-review and editing, N.W. All authors have read and agreed to the published version of the manuscript.

Funding: This research was funded by Hibah Publikasi Doktoral (PD) Universitas Indonesia Tahun Anggaran 2021 grant number: NKB-505/UN2.RST/HKP.05.00/2021.

Institutional Review Board Statement: Not Applicable.

Informed Consent Statement: Not Applicable.

Data Availability Statement: The data used to support the findings of this study are available from the corresponding author by request.

Acknowledgments: The authors would like to express their gratitude to the reviewers for their invaluable guidance. The authors would also like to express their gratitude to National Research and Innovation Agency Republic of Indonesia (BRIN-RI) SAINTEK scholarship and special capital region of Jakarta environment agency (DLH-DKI Jakarta) for their support to this research.

Conflicts of Interest: The authors declare no conflict of interest. The funders had no role in the design of the study; in the collection, analyses, or interpretation of data; in the writing of the manuscript, or in the decision to publish the results. 


$\begin{array}{ll}\text { Abbreviations } & \\ \text { Abbreviation } & \text { Full Form } \\ \text { AHP } & \text { Analytical Hierarchy Process } \\ \text { ANP } & \text { Analytical Network Process } \\ \text { Be } & \text { Beryllium } \\ \text { CRT } & \text { Cathode-Ray Tube } \\ \text { DEMATEL } & \text { Decision making trial and evaluation laboratory } \\ \text { DKI } & \text { Daerah khusus ibukota/special capital region } \\ \text { DLH } & \text { Dinas lingkungan hidup/environment agency } \\ \text { EFE } & \text { Eksternal factor evaluation } \\ \text { EPR } & \text { Extended Producer Responsibility } \\ \text { E-waste } & \text { Electronic waste } \\ \text { FPD } & \text { Flat-Panel Display } \\ \text { IFE } & \text { Internal factor evaluation } \\ \text { Hg } & \text { Mercury } \\ \text { Mt } & \text { Million ton } \\ \text { MVC } & \text { Material value conservation } \\ \text { Pb } & \text { Plumbum/Lead } \\ \text { QSPM } & \text { Quantitative Strategic Planning Matrix } \\ \text { S-O } & \text { Strength-Opportunity } \\ \text { SOP } & \text { Standard Operating Procedure } \\ \text { S-T } & \text { Strength-Threat } \\ \text { SWOT } & \text { Strength-Weaknesses-Opportunities-Threats } \\ \text { TAS } & \text { Total Attractiveness Score } \\ \text { W-O } & \text { Weaknesses-Opportunity } \\ \text { W-T } & \text { Weaknesses-Threat }\end{array}$

\section{References}

1. Ikhlayel, M. Environmental impacts and benefits of state-of-the-art technologies for E-waste management. Waste Manag. 2017, 68, 458-474. [CrossRef] [PubMed]

2. Forti, V.; Balde, C.P.; Kuehr, R.; Bel, G. The Global E-Waste Monitor 2020: Quantities, Flows and the Circular Economy Potential; United Nations University (UNU): Bonn, Germany; United Nations Institute for Training and Research (UNITAR): Bonn, Germany; International Telecommunication Union (ITU): Geneva, Switzerland; International Solid Waste Association (ISWA): Rotterdam, The Netherlands, 2020.

3. Rochman, F.F.; Ashton, W.S.; Wiharjo, M.G. E-waste, money and power: Mapping electronic waste flows in Yogyakarta, Indonesia. Environ. Dev. 2017, 24, 1-8. [CrossRef]

4. Santoso, S.; Zagloel, T.Y.M.; Ardi, R.; Suzianti, A. Estimating the Amount of Electronic Waste Generated in Indonesia: Population Balance Model. IOP Conf. Ser. Earth Environ. Sci. 2019, 219, 012006. [CrossRef]

5. Andarani, P.; Goto, N. Potential e-waste generated from households in Indonesia using material flow analysis. J. Mater. Cycles Waste Manag. 2014, 16, 306-320. [CrossRef]

6. Yoshida, A.; Terazono, A.; Ballesteros, F.C., Jr.; Nguyen, D.Q.; Sukandar, S.; Kojima, M.; Sakata, S. E-waste recycling processes in Indonesia, the Philippines, and Vietnam: A case study of cathode ray tube TVs and monitors. Resour. Conserv. Recycl. 2016, 106, 48-58. [CrossRef]

7. Nurcahyo, R.; Gabriel, D.S.; Ikhsan, W.L. Repetitive implementation of material value conservation and its effects on the mechanical properties of plastic recycling products. Mater. Sci. Forum 2018, 936, 116-120. [CrossRef]

8. Anityasari, M.; Nur, Y.S. Analysis of Success Factors for E-Waste Collection in Indonesia. Appl. Mech. Mater. 2016, 842, 467-472. [CrossRef]

9. Chen, Y.; Chen, M.; Li, Y.; Wang, B.; Chen, S.; Xu, Z. Impact of technological innovation and regulation development on e-waste toxicity: A case study of waste mobile phones. Sci. Rep. 2018, 8, 7100. [CrossRef]

10. Breivik, K.; Armitage, J.M.; Wania, F.; Jones, K.C. Tracking the global generation and exports of e-waste. Do existing estimates add up? Environ. Sci. Technol. 2014, 48, 8735-8743. [CrossRef]

11. Sthiannopkao, S.; Wong, M.H. Handling e-waste in developed and developing countries: Initiatives, practices, and consequences. Sci. Total. Environ. 2013, 463-464, 1147-1153. [CrossRef]

12. Pandebesie, E.S.; Indrihastuti, I.; Wilujeng, S.A.; Warmadewanthi, I. Factors influencing community participation in the management of household electronic waste in West Surabaya, Indonesia. Environ. Sci. Pollut. Res. 2019, 26, 27930-27939. [CrossRef]

13. Chen, F.; Li, X.; Yang, Y.; Hou, H.; Liu, G.J.; Zhang, S. Storing e-waste in green infrastructure to reduce perceived value loss through landfill siting and landscaping: A case study in Nanjing, China. Sustainability 2019, 11, 1829. [CrossRef] 
14. Masud, M.H.; Akram, W.; Ahmed, A.; Ananno, A.A.; Mourshed, M.; Hasan, M.; Joardder, M.U.H. Towards the effective E-waste management in Bangladesh: A review. Environ. Sci. Pollut. Res. 2018, 26, 1250-1276. [CrossRef]

15. Wang, Z.; Huo, J.; Duan, Y. Impact of government subsidies on pricing strategies in reverse supply chains of waste electrical and electronic equipment. Waste Manag. 2019, 95, 440-449. [CrossRef]

16. Islam, M.T.; Huda, N. Reverse logistics and closed-loop supply chain of Waste Electrical and Electronic Equipment (WEEE)/Ewaste: A comprehensive literature review. Resour. Conserv. Recycl. 2018, 137, 48-75. [CrossRef]

17. Cruz-Sotelo, S.E.; Ojeda-Benítez, S.; Sesma, J.J.; Velázquez-Victorica, K.I.; Santillán-Soto, N.; García-Cueto, O.R.; Concepción, V.A.; Alcántara, C. E-waste supply chain in mexico: Challenges and opportunities for sustainable management. Sustainability 2017, 9, 503. [CrossRef]

18. Peng, B.; Tu, Y.; Wei, G. Governance of electronic waste recycling based on social capital embeddedness theory. J. Clean. Prod. 2018, 187, 29-36. [CrossRef]

19. Baidya, R.; Debnath, B.; Ghosh, S.K.; Rhee, S.W. Supply chain analysis of e-waste processing plants in developing countries. Waste Manag. Res. 2020, 38, 173-183. [CrossRef]

20. Doan, L.T.T.; Amer, Y.; Lee, S.H.; Phuc, P.N.K.; Dat, L.Q. E-Waste Reverse Supply Chain: A Review and Future Perspectives. Appl. Sci. 2019, 9, 5195. [CrossRef]

21. Rimantho, D.; Nasution, S.R. The Current Status of e-waste management Practices in DKI Jakarta. Int. J. Appl. Environ. Sci. 2016, 11, 1451-1468.

22. Ambarsari, R.; (Environment Agency/Dinas Lingkungan Hidup Pemerintah Daerah Khusus Ibukota, Jakarta, Indonesia). Private communication, 2021.

23. Ghalehkhondabi, I.; Ardjmand, E. Sustainable E-waste supply chain management with price/sustainability-sensitive demand and government intervention. J. Mater. Cycles Waste Manag. 2020, 22, 556-577. [CrossRef]

24. Xu, Y.; Yeh, C.-H.; Liu, C.; Ramzan, S.; Zhang, L. Evaluating and managing interactive barriers for sustainable e-waste management in China. J. Clean. Prod. 2021, 72, 2018-2031. [CrossRef]

25. Zulkarnain, A.; Wahyuningtias, D.; Putranto, T.S. Analysis of IFE, EFE and QSPM matrix on business development strategy. IOP Conf. Ser. Earth Environ. Sci. 2018, 126, 12062. [CrossRef]

26. Nguyen, H.T.T.; Hung, R.J.; Lee, C.H.; Nguyen, H.T.T. Determinants of residents' E-waste recycling behavioral intention: A case study from Vietnam. Sustainability 2018, 11, 164. [CrossRef]

27. Nduneseokwu, C.K.; Qu, Y.; Appolloni, A. Factors influencing consumers' intentions to participate in a formal e-waste collection system: A case study of Onitsha, Nigeria. Sustainability 2017, 9, 881. [CrossRef]

28. Xu, L.; Ling, M.; Lu, Y.; Shen, M. Understanding household waste separation behaviour: Testing the roles of moral, past experience, and perceived policy effectiveness within the theory of planned behaviour. Sustainability 2017, 9, 625. [CrossRef]

29. Dwivedy, M.; Mittal, R.K. Willingness of residents to participate in e-waste recycling in India. Environ. Dev. 2013, 6, 48-68. [CrossRef]

30. Vieira, B.D.; Guarnieri, P.; Camara e Silva, L.; Alfinito, S. Prioritizing Barriers to Be Solved to the Implementation of Reverse Logistics of E-Waste in Brazil under a Multicriteria Decision Aid Approach. Sustainability 2020, 12, 4337. [CrossRef]

31. Cao, J.; Chen, Y.; Shi, B.; Lu, B.; Zhang, X.; Ye, X.; Zhai, G.; Zhu, C.; Zhou, G. WEEE recycling in Zhejiang Province, China: Generation, treatment, and public awareness. J. Clean. Prod. 2016, 127, 311-324. [CrossRef]

32. D'Adamo, I.; Rosa, P.; Terzi, S. Challenges in Waste Electrical and Electronic Equipment Management: A Profitability Assessment in Three European Countries. Sustainability 2016, 8, 633. [CrossRef]

33. Ghodrat, M.; Rhamdhani, M.A.; Brooks, G.; Masood, S.; Corder, G. Techno economic analysis of electronic waste processing through black copper smelting route. J. Clean. Prod. 2016, 126, 178-190. [CrossRef]

34. Xue, M.; Li, J.; Xu, Z. Management strategies on the industrialization road of state-of- the-art technologies for e-waste recycling: The case study of electrostatic separation-A review. Waste Manag. Res. 2013, 31, 130-140. [CrossRef] [PubMed]

35. Wang, W.; Tian, Y.; Zhu, Q.; Zhong, Y. Barriers for household e-waste collection in China: Perspectives from formal collecting enterprises in Liaoning Province. J. Clean. Prod. 2017, 153, 299-308. [CrossRef]

36. Tiwari, D.; Raghupathy, L.; Khan, A.S.; Dhawan, N.G. A study on the E-waste collection Systems in some Asian Countries with special reference to India. Nat. Environ. Pollut. Technol. 2019, 18, 149-156.

37. Dunford, R.; Su, Q.; Tamang, E. The Pareto Principle. Plymouth Stud. Sci. 2014, 7, 140-148.

38. David, F.R.; David, F.R. Strategic Management: Concepts and Cases: A Competitive Advantage Approach; Pearson: Boston, MA, USA, 2013. 